\title{
Indian Revolutionaries Abroad: Revisiting their Silent Moments
}

\author{
Henrik Chetan Aspengren \\ Department of History, Uppsala University
}

\begin{abstract}
In this article I relate Indian revolutionaries Virendranath Chattopadhyaya's and Lala Har Dayal's experiences of exile in Sweden to recent attempts to reformulate perspectives on Indian anti-colonial protest. These attempts have in various ways focused on the global dimension of Indian anti-colonialism, showing how displaced Indian intellectuals and activists connected outside the Subcontinent, to labour for the freedom of India. While appreciating the need for a fresh approach to studies of anticolonial movements, this article issues a note of caution. Several recent studies treat life in exile as one of connectivity and creativity. In fact, connectivity becomes so important for these studies that it is only when in conversation with others sharing their objective that the views of Indian activists are included. Yet, many exiles lived long periods nearly or actually disconnected from the movement of which they wished to form a part. Such moments of silence are wishfully glossed over in the emerging literature. By way of revisiting Har Dayal and Chattopadhyaya in Sweden, I suggest that periods of silence or disconnection are important, simply because they existed, and formed a decisive part of the reality of exile. By omitting them, one risks romanticising exile, and subjecting experiences of displacement to academic programmatic concerns, however noble the cause.
\end{abstract}




\section{A Reformulated Approach to Indian Anti-Colonial Protests}

Indian historiography has to a large extent placed nationalist or anti-colonial protest within the geographical frame of South Asia, subaltern studies being no exception. Yet recent nonfiction and academic work show that far from being restricted by the borders of the Subcontinent, anti-colonial sentiment was articulated on a global scale. Or perhaps, better put, anti-colonialism was simultaneously pronounced by activists at home and abroad, in networks transcending territorial boundaries. Studies show that Indian and other Asian political activists displaced to various localities in Asia, Europe and North Africa formed zones of conversation through which visions of an end to European empire were conjured. ${ }^{1}$ Even in London, the heart of empire, Indian nationalist revolutionary ideas were flowing quite freely, at least until the First World War. $^{2}$

Key concepts in this reformulated approach to Indian anti-colonial activism are: "Flow," "circulation" and "connectivity," emphasising continuous engagement and action. By highlighting connections across continents the studies successfully, geographically speaking, re-scale anti-colonial thought and action. This is promising in at least two ways. First, on a theoretical level, it unlocks nationalist and anticolonial movements from what are often perceived as their locally situated struggles. It shows that resistance to colonialism could be analysed through a wider lens. Doing so enables us to move beyond analytical models of metropole and periphery, and toward less Eurocentric conceptions to which a variety of non-Western and Western settings and voices may contribute. Second, on an empirical level, it brings to our attention the actual working of the many and sometimes dense networks of anti-colonialism that connected various locations of the world, and to the circulation and continuous reformulation of political ideas and moral indignation within these networks.

Indeed, as recent studies show, the transnational networks set up by Indian anti-colonial activists were impressive. They provided opportunities for some of those displaced from India to fold into multi-ethnic and ideologically diverse settings of European and Asian capitals, and to become "interfaces and interpreters" in contacts between activists from various locations in Asia, Europe and North Africa. ${ }^{3}$ 
And, to some extent, this kind of "transborder circulations of people, concepts and fashions in the anticolonial age" that the networks made possible, "galvanized nationalist politics and inspired artistic and literary production."

The emphasis placed in recent studies on cosmopolitan connections of anticolonial resistance makes for a compelling narrative, and the idea of border-defying revolutionaries, at home everywhere, was sometimes promoted by the activists themselves, as an inspiration to others. Yet, this article issues a note of caution. The strong focus on circulation of thought and action through global networks seems to give rise to a temptation to valorise exile as a condition of creativity and connectivity. Every new place where the activist set foot, or so it seems, served up new contacts bearing on the political work of the émigré, or provided fresh opportunities to advance the cause. It is as if inherent in displacement lay the possibility of progression, rather than the spectre of disjunction.

For many activists, however, life in exile was for long periods of time far from inspirational, and had very little connectivity to offer. Rather, for them, displacement was just as restricting and frustrating, emotionally painful and economically insecure, as Edward Said so perceptively noticed in his celebrated essay Reflections on Exile. ${ }^{5}$

In this article I will turn to the years of Swedish exile experienced by Lala Har Dayal and Virendranath Chattopadhyaya, brother of the Indian nationalist poet Sarojini Naidu. Chattopadhyaya and Har Dayal were two vocal Indian nationalist revolutionaries, who engaged the cause of Indian self-determination in different ways, for decades. Both left India for England in the early twentieth century, both were absorbed by the radical political milieus of London during the first decade of that century, and both felt forced to leave Britain for lifelong migration, before the end of the same decade.

As we shall see, for Chattopadhyaya and Har Dayal, although they were vocal and prominent in the nationalist revolutionary movement, displacement did not only imply inclusion into cosmopolitan conversations; it also meant a periodic fall out of 
such conversations, and from the interconnected political struggle they had embraced.

For them, the lived experience of exile meant that they for stretches of time had to face depression, financial hardship and exposure to the arbitrary dealings of local authorities. Also, if judged by the very conservative local contacts they both were left with upon arrival in Sweden, a great deal of self-evasion must have been exercised, at least by Chattopadhyaya, who at times liked to portray himself as a communist revolutionary.

In fact, for both Chattopadhaya and Har Dayal, as we shall see, the pressure of displacement contributed to periods of unwinding political activities and reconsideration of political views. A similar fate was bestowed on scores of other political activists in displacement, before, then, and after.

\section{Working for a Revolution in India from Afar}

During the first decades of the twentieth century, Indian activists laboured from afar for a revolution on home soil. Some of them had directly or indirectly been forced into displacement; others felt they could enjoy more freedom, or better conditions, outside the jurisdiction of the Government of India. The two activists who will figure most prominently in this article, Lala Har Dayal and Virendranath Chattopadhyaya, are in some respects emblematic in recent writing on cosmopolitan Indian activism. They travelled widely and were, during certain periods, important in the mobilisation of efforts outside India to carry out change on the Subcontinent.

Both Lala Har Dayal and Virendranath Chattopadhyaya had come to revolutionary thought and action not in India, but in England. Chattopadhyaya grew up in the 1880s in Hyderabad, then a princely state in India. His father was a professor and the principal of Nizam College. Chattopdhyaya studied at the Calcutta University before arriving in London for attending the Indian Civil Service examination. Failing those he took up law studies at Middle Temple. During his first years in England, Chattopadhyaya seems to have led a quiet life, focusing on his studies and trying to find his bearing in England. ${ }^{6}$ 
Har Dayal, the younger of the two, engaged radical politics soon upon arrival in Britain. He too had been raised in a well-educated family; his father was a reader in the District Court in Delhi. Har Dayal attended the University of the Punjab, and after brilliant results he was selected for a prestigious state-financed three-year scholarship at Oxford, and although he had already made critical remarks on British rule in India in Lahore, he was allowed to leave for England. ${ }^{7}$

In Oxford however, Har Dayal gave up his scholarship in 1907, before finishing his degree, on ideological grounds. He left the university and instead attached himself to the radical circle forming around the activist scholar Shyamji Krishnavarma in London. Har Dayal's decision to prematurely end his scholarship gave resonance with Krishnavarma, and placed him at the centre of the activities of the group. From London, and later from Paris, Krishnavarma ran the radical weekly Indian Sociologist, to which Har Dayal was a frequent contributor. Krishnavarma also financed the India Home Rule Society, which gave out grants for housing and lodging at the India House in London's Highgate. Krishnavarma invited young Indian radicals to accept his grant, but on the condition that they agreed to never enter the service of Government of India.

Virendranath Chattopadhyaya was also drawn to Krishanvarma's circle. Initially he acted in the margins of the group, taking a less radical view on developments in India, but after some time he too began to contribute to the activities at India House.

However, after Krishnavarma's departure for Paris, the group in Highgate was taken over by V.D. Savarkar, who promoted a much more activist agenda for the group than before. In 1908, an activist connected to India House murdered Curzon Whilie, an employee at the Indian Office in London. The murder brought out tensions within the group and also led to growing official hostility towards the Indian radicals in London. Ultimately the group broke up and spread across continents.

Har Dayal went to Paris, Algiers and Martinique, before landing in San Francisco. In California, while studying at Stanford, he was instrumental in founding the Hindu Association of the Pacific Coast, and the Ghadar-party, hoping to enlist the 
Indian community residing there in the struggle for revolution in India. ${ }^{8}$ The Ghadarparty was initially a Punjabi oriented organisation. It ran a Punjabi edition as well as an Urdu edition of its paper Ghadar, and had specific interests in revolutionary activities in the Punjab. As it developed, however, the Ghadar-network grew in scope and numbers and was heavily involved in the "chain of rebellions" in South and South East Asia, including the Singapore rebellion of 1915. Throughout its activities the Ghadars operated in connection with the German Foreign Ministry, which would lend logistical and financial support. ${ }^{9}$ In 1914, however, as the First World War broke out, Har Dayal's activities in California became known to US authorities, and he felt forced to leave for Berlin.

In Berlin he met with Chattopadhyaya, who had done a stint in Paris after leaving London. Berlin was at the time, in the words of Har Dayal "a Mecca for Oriental Patriots." ${ }^{10}$ German officials were interested in challenging British interests, and looked for opportunities to undermine Britain's hegemony. Germany sensed, at this time, a growing resentment towards British rule among minorities within the British Empire. If they could ferment that resentment, and channel it through active although clandestine operations, they thought they might deliver severe blows to the British.

The German Foreign Ministry assumed that India was vital to the interests of the British Empire, both in the immediate term concerning the war effort, and for its long-term standing in the world. They also assumed that forces in India showed the most mature and best-coordinated opposition to British rule. Through an organisation set up by Chattopadhyaya, among others, in Berlin, he became instrumental to the German efforts to mobilise Indian discontent. Har Dayal was also involved. Both of them were indirectly financed and supported by the German Foreign Ministry.

As their contacts in Berlin became increasingly interested in Muslim resentment towards the British, Chattopadhyaya and Har Dayal set up an office in Constantinople in the German-allied Ottoman Empire, hoping that they could coordinate efforts to stir up Central Asia. ${ }^{11}$ 
From Berlin and Constantinople, then, Chattopadhyaya and Har Dayal were involved in anti-British agitation in Europe, in mobilising anti-colonial sentiment in Punjab, in attempts to traffic weapons from the United States in order to arm Indian revolutionaries, and in trying to enlist the emir of Afghanistan to let bands of revolutionaries pass through Afghan territory on their way south to ignite revolution in India. The emir, however, declined involvement. ${ }^{12}$

While Chattopadhyaya's and Har Dayal's anti-British agitation was successful to some extent, their more spectacular ventures to mobilise an Indian revolution failed for a variety of reasons: The interventions by British intelligence services, disconnect between German officials and Indian activists, and infighting within the group of Indians. But perhaps more important, the revolution was not as imminent in India as they and their fellow activists liked to believe.

\section{Displaced up North}

The First World War and the Bolshevik revolution of November 1917 had considerable impact on the view on India taken from European capitals. From London and Delhi came mixed messages. The then secretary of state for India, Edwin S. Montagu, called for constitutional reforms and increased Indian political influence through "dyarchy" as a way to handle mounting political pressure in India. At the same time the draconian wartime laws of the Defence of India Act of 1915 found their continuation in the Rowlatt Acts of 1919, and the repressive practises connected to those laws continued into the 1920s; the fear of urban and cantonment unrest was tangible. ${ }^{13}$

Berlin's interest in Indian revolutionary activities cooled down considerably, however, as the fortunes of war turned against Germany. Har Dayal and Virendranth Chattopadhyaya sensed the turn in mood in the German capital and made plans to leave Berlin. They were barred from entering India and, were they to go elsewhere in the British Empire, they risked being arrested and jailed as British authorities tried in every way possible, including murder, to circumscribe their activities. ${ }^{14}$

Both activists, independently, applied for visas to Sweden. Perhaps not an obvious choice when agitating the cause of Indian freedom, but their contacts in 
Germany were well connected to influential circles in Sweden, paving way for the two Indian revolutionaries to access intellectual and political networks. Also, Sweden was neutral in the First World War and not yet as forthcoming to British interests as it would become only a few years later. The country's neutrality would bring security, or at least that was what Chattopadhyaya thought, and as he would later write to the Swedish Foreign Ministry in his application for prolonging his visa of entry: "[B]eing a political refugee whose life and liberty have often been in danger at the hands of the British Government, there is no country except Sweden where I can safely reside." 15

Yet a more important factor in going to Sweden, at least for Chattopadhyaya, was that European socialists planned to arrange a peace conference in Stockholm in 1917. The conference committee consisted of social democrats and socialists from Scandinavia and the Netherlands, and later delegates from Russia also joined. ${ }^{16}$ They were inviting various socialist groups as well as representatives of subjected nationalities within the European and Ottoman empires, to confer on how to end the First World War and create a lasting peace and national self-determination. Sections within the German Foreign Ministry as well as activists from several locations of the British Empire hoped to use the conference to further their nationalist and anti-British interests. ${ }^{17}$

Virendranath Chattopadhyaya's application for a visa to Sweden was initially rejected, but he was eventually granted permission and arrived in the port town of Trelleborg in southern Sweden on 12 May $1917 .{ }^{18}$ He stated that his reason for applying for a visa was to engage in "literary work for the Indian National Movement and for World Peace. It is my intention to reside permanently in Sweden and to apply for naturalization as a Swedish Subject."19

Har Dayal left Berlin for Vienna, where he got stuck for a year, as his initial application to enter Sweden was rejected too. ${ }^{20}$ Finally he was granted a visa from 1 October 1918. Har Dayal referred to himself as a "university professor," but like Chattopadhyaya he also stated that he would occupy himself with "literary work" while in Sweden. ${ }^{21}$ 
In their first applications to be granted permission to stay in Sweden, Har Dayal and Chattopadhyaya referred to the same local contacts. All their contacts were political conservatives who warmed towards Germany. This was not uncommon in Sweden at the time; but the people the two revolutionaries referred to were not only outspoken friends of Germany, but also explicitly critical towards Britain. Harald Sohlberg, then owner and editor of the Swedish daily Aftonbladet often ran highly critical opinion pieces against British interests, drawing critical remarks from the Swedish Foreign Ministry. ${ }^{22}$ Both Sohlberg and the other references of Har Dayal and Chattopadhyaya-Dan Akerhielm, editor at the conservative newspaper Gefle-bladet, and Leonard Ljunglund, editor at the daily Nya Dagligt Allehanda - came out strongly against socialism and actively tried to disrupt unionization at their workplaces. Also, Ljunglund held anti-Semitic views. ${ }^{23}$ Both Har Dayal and Chattopadhyaya also mentions Annie Åkerhielm, a writer and wife of Dan Åkerhielm, who would later publicly show her regard for German Nazism. ${ }^{24}$

Chattopadhyaya busied himself upon arrival in preparation for the conference. He set up office on the first floor, Artillerigatan 28 B, in Stockholm. The building was centrally located in a part of the town that was quite affluent, although the archives reveal the middle class occupations of his neighbours: Craftsmen, middle ranking officers and senior clerks. ${ }^{25}$

In 1917 Stockholm was brimming with political activity of international significance. Partly this was due to the Stockholm Peace Conference with its hundreds of foreign delegates, but it was also due to the many émigrés and activists who travelled to and from Russia at the time of the Bolshevik revolution. Moreover, Stockholm's location and neutrality combined with various forms of foreign organised political activity made it interesting for intelligence agencies from various countries. Given the amount of foreign activity in Sweden at the time, Swedish authorities had established a special branch of the police that had as its main purpose to surveil foreigners travelling through or residing in Sweden. A detective from that branch of the police noted in a report that on the first floor of Artillerigatan 28, where Chattopadhyaya had his bureau, were also the offices of a New York-based group called Friends of Irish Freedom, and the former US consul to Munich turned Irish activist, Thomas John Gaffney. ${ }^{26}$ 
As part of the preparations for the peace conference, the conference committee consulted with over a hundred delegates, and Chattopadhyaya met with the two main organisers, Pieter Jelles Troelsta and Hjalmar Branting, on 12 July 1917. In the meeting Chattopadhyaya argued that in a future conference for world peace India must be represented by a delegation that is legitimate. ${ }^{27}$ However, in statements for the press in connection to his meeting he did not express high hopes for the peace conference, and he did not find the organisers very supportive of the struggle for freedom of those subjected to British rule. ${ }^{28}$

Yet, as it turned out the peace conference in Stockholm never opened. This was a severe blow to Chattopadhyaya's activities, as he lost a platform for raising his political concerns. He had to work even harder to get attention from the press, as well as from local politicians and activists, regarding the issues he hoped to raise.

Moreover, he found that the tides turned against those who tried to bring to the attention of European audiences the situation in India. The organising committee for the conference issued a manifesto for peace, with which Virendranath Chattopadhyaya was deeply dissatisfied. He submitted a written protest in the form of a pamphlet, containing strong wording asserting that for Western European social democrats "the term humanity only refers to Europe." 29

Funding from Germany was uncertain after the end of the First World War. Both Chattopadhyaya and Har Dayal quickly understood that being seen as an ally of Germany was not beneficial to their cause, and tried to find new friends in Sweden. Although a gifted networker, it took some effort for Chattopadhyaya to redirect his local network from its initial bias towards German-friendly conservatives to liberals, socialists and social democrats, who were looking a much safer bet.

Already during the latter part of 1918 Chattopadhyaya was encouraged by his contacts in Sweden to find new sources of income, but that would mean that he could no longer commit to full-time activism. The Swedish police, moreover, advised him to reduce his political activities. ${ }^{30}$ To do so implied tempering his political writing and turning to less divisive topics. 
With restricted possibilities for raising nationalist or anti-colonial issues from his Swedish exile, and with far from secure legal status in the country, he began to temper his political activism. Instead he hoped to turn to teaching and writing on Indian history. He was hired to contribute to a book on Asian history, and he also tried to sell articles and reviews to Swedish newspapers. At one point he is even thought to have made inquiries whether he could become a partner in a local translation and communication agency, according to a clerk employed at the Swedish Parliament, who gave evidence to the Swedish police on Chattopadhyaya. ${ }^{31}$

Less than two years after his arrival in Sweden Chattopadhyaya began to reconsider the form of his operations. In an application to the Swedish Foreign Ministry for a prolonged permit to reside in Sweden he gives the qualified assertion that his "bureau has now been closed as propaganda is not desirable at present." 32

Similarly, Har Dayal began distancing himself from political activities upon arrival in Sweden in October 1918. He stayed at a sanatorium in Saltsjöbaden outside Stockholm. The Swedish Foreign Ministry enquired almost immediately into his connections with Virendranath Chattopadhyaya, as the British legation had begun alerting Swedish authorities on Chattopadhyaya's activities.

In a reply to Swedish authorities Har Dayal wrote in late December 1918 that he was prevented from returning to India and that the German government was too weak to protect him from extradition to Britain. If it was necessary in order for him to stay in Sweden, he could, he wrote, discontinue his political work, and he begged to be granted permission to stay at least until the end of the war. If the Swedish government were to decide that he must leave Sweden, he asked permission to travel to Holland or Spain. If such permission were denied, Har Dayal writes, he would commit suicide. $^{33}$

Literally overnight he seemed to have come to a conclusion because the very next day after he issued his first letter, he sent a new letter to the Swedish Government: 
I beg to inform you that I have decided to discontinue my political work here, as you have kindly advised.... I have come to the conclusion that it would be foolish and useless to carry on revolutionary propaganda against England in the near future. ${ }^{34}$

Simultaneously he began to distance himself from Virendranath Chattopadhyaya. He wrote again to the Swedish Foreign Ministry a little more than a month later, stating, "I have now no joint responsibility for the actions of my compatriot Mr V Chattopadhyaya, or of other Indian gentlemen living in Sweden."35 Later that same month he again informed the Swedish authorities "I have now no connection with the 'Indiska Nationalkommittén' here, as there has been very serious differences of opinion."

This was not the first time Har Dayal had distanced himself from the nationalist revolutionary movement while in exile. Neither was this the first time he had gone into seclusion or used dramatic language. In 1910, when in Algiers, upon leaving Paris, he wrote sincere letters to his friend in Paris, Sardar Singh Rana. He said he liked Algiers, the town reminded him of Bombay, yet he had been under much pressure and emotional strain, and it took its toll, physically and mentally. ${ }^{37}$ Even in Paris he had been ill fed and troubled by his bronchial problems. ${ }^{38}$ Leaving Paris was disruptive. He had fallen out with Krishnavarma, whom he called a coward, and whom he accused of setting up India House for his own vanity and selfadvertisement. ${ }^{39}$ He was depressed over the disruption caused to his own affairs by the murder of Curzon Whilie in London. ${ }^{40}$ He was feeling better, he wrote to Rana after some time, and he had taken up playing the mandolina because his doctor had told him to be "habitually gay," yet, he wrote, "I often find relief in crying. It is good for me."41 Leaving Paris abruptly, he left his only friends, he wrote, although he felt parting ways was necessary. “As to other people's opinion about me, I don't care and besides, I am above slander, as everyone who knows me loves me."42

\section{Marginalised by British Intelligence and Swedish Authorities}

As Virendranath Chattopadhyaya stayed back in Stockholm although the peace conference never materialised, British authorities began to monitor his whereabouts. 
They forwarded information regarding language courses he planned for the adult education institution Borgarskolan to the Swedish Foreign Ministry. They in turn sent the information to the home secretary, suggesting that the event ought to be monitored. ${ }^{43}$ Trying to further his income Chattopadhyaya wrote articles and reviews on topics relating to South Asia, and he also took to translating for a newly founded agency called Universal. ${ }^{44}$ Moreover he started to work for an import agency with business in Estonia, Germany and Russia. The manager of the firm, a Ms. Cecilia Håkansson, sent Chattopadhayaya abroad and he made several applications to be granted travel visa for business trips to Reval (now Tallinn) and Berlin. In a letter to the Swedish Foreign Ministry Håkansson asserts that Chattopadhyaya had closed his Indian bureau before 1920, and had not been engaged in political issues since then. ${ }^{45}$

The Swedish consul in Reval, however, was alerted by the British special mission to that city that Chattopadhyaya might, instead of visiting Estonians firms, be consulting with Bolshevik revolutionaries. British authorities provided the Swedish consul with alleged intelligence information on meetings Chattopadhyaya supposedly had, and the consul transmitted the information without caveats to the Foreign Ministry in Stockholm. The telegrams suggested that Chattopadhyaya was a most dangerous agitator, who barricaded himself for three weeks in the hotel where the Bolsheviks resided. ${ }^{46}$

Also, the British information submitted to the Swedish consul insisted that he would return to Sweden on board a ship that formed part of a fleet of 18 ships that the Bolsheviks had acquired to be used to transport propaganda material across the Baltic Sea. The consul suggested that the ships would anchor on the outskirts of Stockholm's archipelago and empty their cargo of seditious literature on remote islands, in order for it to be picked up for distribution on land by couriers in Sweden. ${ }^{47}$ The Swedish Customs and harbor authorities replied to the enquiry made by the Foreign Ministry that they had knowledge of neither such shipments nor boats.

Virendranath Chattopadhyaya was allowed to return from Reval, but on his next business trip to Germany on behalf of Cecilia Håkansson's firm, in March 1921, he was denied re-entry into Sweden. His Swedish friends and contacts initiated a campaign for having the ban revoked. A Swedish parliamentarian, Carl Lindhagen, 
asked a question in the Swedish Parliament and received an answer from the then prime minister, Oscar von Sydow. ${ }^{48}$ The prime minister's answer was stuffed with intelligence from British sources, as shown by a memorandum compiled for the reply to the Parliamentary question. ${ }^{49}$

From Moscow, Chattopadhyaya issued a long reply to von Sydow, in which he tried to clear his name. The reply was published in two subsequent articles in a Swedish paper. In the first article he detailed how Swedish authorities had been well aware of the character of his work, and did not mind it, at least until the end of the First World War. ${ }^{50}$

The second article is to a large extent devoted to counter allegations of him being part of a conspiracy in Switzerland during the war, but its most interesting feature is how explicit Chattopadhyaya is in his references to himself as a communist revolutionary. Such descriptions were not at all frequently used in his writing from Stockholm. ${ }^{51}$ None of his articles, however, had any impact upon the decision made by the Swedish government.

It has been documented by Barooah that Chattopadhyaya, after having been turned away from Sweden, left Germany for Russia. He was affiliated to the University of Leningrad, where he lectured in anthropology, but for some reason, to me unknown, he was arrested by Stalin's secret police. According to a death certificate given to his Russian wife in 1958, Chattopadhyaya died in 1943 under unclear circumstances. ${ }^{52}$

While his experiences of displacement ultimately forced Chattopadhyaya into a period of involuntary silence in matters political, Har Dayal made a complete change of political mind. From Stockholm he published a series of articles and then a book issuing a devastating critique of German foreign policy and the character of the German people. While finding all forms of imperialism an evil, everyone who had experienced the First World War must see that the British Empire was to be preferred to an extended German Empire, suggested Har Dayal, as he called for Indian autonomy within British Empire. He was also being highly critical of his fellow Indian activists in Europe. His new position was commented on in various 
outlets. The New York Times referred at length to the articles and to the "remarkable effect" displacement had had on tempering Har Dayal's political views. ${ }^{53}$

By 1920, he given up on revolutionary agitation, he turned away from the political movement he was once so involved in, and instead went on to study poetry, education, religion and history. This did not mean that he stopped developing views on Indian nationhood and independence, but he did not try to mobilise other behind his ideas or agitate for Indian self-determination.

After leaving Stockholm, he went to Uppsala, using the university town as a base for lecturing in other nearby towns. He got himself involved with organisers of adult education, especially within the temperance movement and workers' educational societies and associations. ${ }^{54}$ The study groups were concerned with knowledge transfer but also social reform and self-culture, and they placed their pedagogical emphasis on collective learning for adults through self-organised study groups. The groups had autonomy, although forming part of wider associations for adult education. The associations, in turn, were civil-society-based and did not belong to the state-financed formal education system.

Har Dayal even took up an offer to move to and lecture at a college that formed part of this informal Swedish education system, in the small town of Mölnlycke. In Mölnlycke, he lived an ascetic life, rented a room from a local gardener and his wife, and divided his time between reading, teaching and seeing his many new local friends. ${ }^{55}$ Many of those friends were active within the Swedish popular colleges or adult education associations. ${ }^{56}$ A couple of years or so after moving, however, Har Dayal met his future wife, Agda Erikson, and they moved in together in her home town of Borås. A little later he left Sweden to pursue a Ph.D. at the School of Oriental and African Studies in London, after British authorities had granted him and selected other activists amnesty.

Har Dayal's connection to Swedish adult education was not political in any explicit sense. It was not something that he brought to bear on his work within the anti-colonial movement, yet as Kapila Shruti has touched upon, the ways in Har Dayal in the 1920s elaborated with new ideas of selfhood and education may have 
played into his wider views on nationalism and internationalism. ${ }^{57}$ Some of these new ideas could be seen in Har Dayal's book Hints for Self Culture, ${ }^{58}$ a book that expands some of his early ideas published in the Swedish adult education periodical Studiecirkeln. In his article Har Dayal set out, in brief terms, a program for lifelong learning, dividing knowledge into four domains: Physical, intellectual, aesthetics and ethics. $^{59}$

After Har Dayal's demise in Philadelphia in 1939, where he had gone to lecture, Erikson would bring his ashes back to Sweden. ${ }^{60}$ After renouncing his political adherence to revolutionary Indian nationalism in Sweden he was never to form part of the movement again.

\section{Conclusion: Revisiting silent moments}

In this article I have revisited Virendranath Chattopadhyaya's and Lala Har Dayal's period of exile in Sweden. Both of them were active in international networks of anti-colonial protest, and as such they have been included in recent writings on the global dimensions of Indian nationalist and anti-colonial activism.

As I have argued above, it seems very fruitful that recent studies of Indian anti-colonial sentiment have find ways to refocus, so that activism in India as well as abroad are similarly appreciated, and placed in relation to each other. This new approach to anti-colonial movements charts networks and connections that are simultaneously global and local, and in doing so it defies the impulse to make the territorial state a default point of reference. The role of activists exiled from India by colonial decree, or displaced through other measures, even self-imposed, are central to the new approach in studies of anti-colonial activism. Exiled Indian activists often travelled restlessly, and their lives easily lend themselves to concepts such as "cosmopolitan" or "transnational."

With this I have no quarrel. Yet, I have argued, when shifting focus in studies of anti-colonial thought and action from one locale to many, from situated struggles to networks, we must remind ourselves, that it is we, with hindsight, who connect the dots in those networks, it is we who chart the circulation of ideas and practices between activists in those locales. 
It is tempting, when making those connections, to forget that the lived reality of exile was not always as intellectually stimulating and creative as one might be led to believe. The liberal use of concepts such as "flow" or "connectivity" in recent studies of anti-colonial networks, when discussing experiences of exile, seem to me to indicate rather wishful forgetfulness at work.

Instead, I would say, in the very moment of unfolding events, things must have looked rather bleak and chaotic from the perspective of those displaced activists and thinkers whom we study. For example, it seems clear that local circumstances in Sweden had a direct and restricting impact on both Virendranath Chattopadhyaya's and Lala Har Dayal's ability to conduct the kind of work they first set out to do. Not long after their arrival, they became unsure of whether they would get anything at all done from Sweden, if they were to stay, if they would be arrested, or even deported. Insecurity concerned not only terms of income and legal status, but also questions of whom to rely on in a new environment. Such experiences had a strong effect on the thinking and acting of Har Dayal and Chattopadhyaya. It seems that a better term to use than "connectivity" when discussing their experience of exile in Sweden, in relation to the movement they embraced, would be "silence" or "disconnection."

Perhaps it might be that periods of reclusion or falling out from anti-colonial networks, however short, were important in a way, as they could have amounted to moments of intense introspection or questioning of previous ideas and tactics. A closer study of such moments of silence than I have been able to provide here might give insight into the inception or reconfiguration of anti-colonial thought that was later to be pushed through global networks.

Yet the most important issue at stake for now, however, is how to combine a theoretically informed view on anti-colonial thought and action that brings out the many sided and border-transgressing character of the struggle, with a humane and nuanced approach to the histories of those displaced individuals involved. When writing such histories we must begin by paying close attention not only to their productive or creative moments, but also to their many moments of anxiety and despair. 
For correspondence: henrik.c.aspengren@hist.uu.se. The author would like to thank Margaret Hunt, and the anonymous reviewers for valuable comments. Research for this article has been financially supported by the Swedish Research Council.

\section{Notes}

${ }^{1}$ Sugata Bose and Kris Manjapra, eds., Cosmopolitan Thought Zones: South Asia and the global circulation of ideas (Basingstoke: Palgrave Macmillan, 2010); Harald Fischer-Tiné, “'Indian Nationalism and the World Forces': Transnational and diasporic dimensions of the Indian freedom movement on the eve of the First World War," Journal of Global History 2 (2007): 325-44; Pankaj Mishra. From the Ruins of Empire: The revolt against the West and the remaking of Asia (London: Allen Lane, 2012); Benjamin Zachariah, "A long, strange trip: The lives in exile of Har Dayal," South Asian History and Culture 4 (2013): 574-92.

${ }^{2}$ Nicholas Owen. "The Soft Heart of the British Empire: Indian radicals in Edwardian London," Past and Present 220 (2013): 143-81.

${ }^{3}$ Fischer-Tiné, "Indian Nationalism and the World Forces," 330.

${ }^{4}$ Kris Manjapra, "Introduction," in Cosmopolitan Thought Zones: South Asia and the global circulation of ideas, ed. Sugata Bose and Kris Manjapra (Basingstoke:

Palgrave Macmillan, 2010), 2.

${ }^{5}$ Edward Said, Reflections on Exile and Other Essays (Cambridge: Harvard University Press, 2000), 173.

${ }^{6}$ Nirode K. Barooah. Chatto: Life and times of an Indian anti-imperialist (Delhi:

Oxford University Press, 2004).

${ }^{7}$ Emily C. Brown, Har Dayal: Hindu revolutionary and rationalist (Tucson: The University of Arizona Press, 1975).

${ }^{8}$ Brown, Har Dayal, 127.

${ }^{9}$ Tim Harper, "Singapore, 1915, and the Birth of the Asian Underground," Modern Asian Studies 6 (2013): 1792-93.

${ }^{10}$ Lala Har Dayal, Forty-four Months in Germany and Turkey, February 1915 to

October 1918: A record of personal impressions, (London: P.S. King and Son, 1920), 55 .

${ }^{11}$ Brown, Har Dayal, 183.

${ }^{12}$ Barooah, Chatto, 63. 
${ }^{13}$ Henrik Chetan Aspengren, “Empire: 'A question of hearts'? The social turn in colonial government, Bombay c. 1905-1925," in Empire, Development and

Colonialism: The past in the present, ed. M. Duffield and V. Hewitt (London: James Curry, 2009), 50-55.

${ }^{14}$ Barooah, Chatto, 137.

${ }^{15}$ Virendranath Chattopadhyaya to Utrikesdepartmentet (UD) [Swedish Foreign Ministry]. 28 January 1919, volym (vol). F10 A:3, dossier (dos.) P 90 0,

"Chattopadhyaya, Virendranath," Statens Utlänningskommission Hemliga arkivet (SUK) [National Alien Commission, Secret Archives], Riksarkivet (RA) [Swedish National Archives], Stockholm.

${ }^{16}$ Martin Grass, “"Fredsfrågan i Stockholm 1917-ett hot mot de krigsförande makterna," Arbetarhistoria 12 (1988): 9-14.

${ }^{17}$ Martin Grass, ““Tio muselmän redogöra för sina nationers slaveri.' Representanter för islamska folk i Stockholm 1917," Arbetarhistoria, 25 (2001): 42-49.

${ }^{18}$ Application from Chattopadhyaya, 28 February 1919, dos. E 8 A: 15 U 1856, Statens Polisbyrå (SP) [National police bureau for surveillance of foreigners residing in the country], RA.

${ }^{19}$ Application from Chattopadhyaya, 26 October 1918, vol. F10 A:3, dos. P 900 , SUK, RA.

${ }^{20}$ Erik Hallgren, memorandum, 3 December 1917, vol. F1884, dos. F2A: 161, "Har Dayal, Lala," SUK, RA.

${ }^{21}$ Questionnaire no. 214, 8 September 1918, vol. F1884, dos. F2A: 161, "Har Dayal, Lala," SUK, RA.

${ }^{22}$ Torvald Höjer to Harald Sohlberg, 9 September 1914, ACC 1974/51, Harald Sohlberg's papers, Kungliga Biblioteket (KB) [Swedish Royal Library], Stockholm. ${ }^{23}$ Göran Nilzén, "Leonard (Leon) C W Ljunglund”, entry in Svenskt Biografiskt Lexikon, 24 (1982-84), 36.

${ }^{24}$ Bibi Jonsson, “Annie Åkerhielm: nazist och feminist?,” in I ordets smedja: festskrift till Per Rydén, ed. K.E. Gustafsson (Stockholm: Carlsson, 2002), 228-40. 25 “Artillerigatan 28 B,” Adresskalendern för Stockholms Stad, 1917, 1236.

${ }^{26}$ Memorandum, n.s., 25 October 1917, vol. F 3: 4, dos. H II 125, "Hetzenstein, Heinrich," SUK, RA. 
${ }^{27}$ Sitzung des Holländisch-skandinavischen Komitees mit der Delegation aus Indien, P/55, 12.7.17, www.labourhistory.net/stockholm1917, accessed 4 May 2012.

28 "På indiska byrån," Aftonbladet, 10 July 1917; “En intervju på indiska byrån i

Stockholm," Svenska Dagbladet, 12 July 1917.

${ }^{29}$ Indiska Nationalkommittén, En protest mot den Holländsk-Skandinaviska

kommittén (Stockholm: Andrén och Holms Boktryckeri, 1918).

${ }^{30}$ Chattopadhyaya to UD 28 January 1919, vol. F10 A:3, dos. P 90 0, SUK, RA.

31 Memorandum, n.s., 23 February 1919. vol. F 3: 4, dos. H II 125, RA, SUK.

${ }^{32}$ Application by Chattopadhaya, 28 February 1919, E 8 A: 15 U 1856, SP, RA.

${ }^{33}$ Har Dayal to UD, 23 December 1918, F1884, dos. F2A: 161, 'Har Dayal, Lala', SUK, RA.

${ }^{34}$ Har Dayal to UD, 24 May 1918, F1884, dos. F2A: 161, 'Har Dayal, Lala', SUK, RA.

${ }^{35}$ Har Dayal to UD, 1 February 1919, F1884, dos. F2A: 161, 'Har Dayal, Lala', SUK, RA.

${ }^{36}$ Har Dayal to UD, 20 February 1919, F1884, dos. F2A: 161, 'Har Dayal, Lala', SUK, RA.

${ }^{37}$ Har Dayal to Sardar Singh Rana, 1 May 1910, Har Dayal papers, Nehru Memorial Museum and Library (NMML), Delhi,

${ }^{38}$ E. Jaiwant Paul and Shubh Paul. Har Dayal: The great revolutionary (New Delhi: Roohli Books, 2003).

${ }^{39}$ Har Dayal to Rana, (n.d.), 1910, Har Dayal papers, NMML.

${ }^{40}$ Har Dayal to Rana, (n.d.), 1910, Har Dayal papers, NMML.

${ }^{41}$ Har Dayal to Rana, (n.d.), 1910, Har Dayal papers, NMML.

${ }^{42}$ Har Dayal to Rana, 18 December 1908, Har Dayal papers, NMML.

${ }^{43}$ UD to Civil Departementet [Swedish Home Ministry], 27 January 1919, vol. F 3: 4, dos. H II 125, SUK, RA.

${ }^{44}$ Sven Strömberg to Padman (Padmanabhan) 2 May 1955, deposition 191, Svenskindiska föreningen [Swedish-India Association], KB.

${ }^{45}$ Cecilia Håkansson to UD, 29 March 1921, vol. F10 A:3, dos. P 90 0, SUK, RA.

${ }^{46}$ Telegram from the Swedish consulate in Reval to UD, 1 April 1921, F 1 B:1, dos. 661 1921, SP, RA. 
${ }^{47}$ Telegram from the Swedish consulate in Reval to UD, 18 April 192, vol. F10 A:3, dos. P 90 0, SUK, RA.

${ }^{48}$ Extracts from interpellations in the Swedish Parliament, reply to Carl Lindhagen from Prime Minister Oscar von Sydow, 14 June 1921, in vol. F10 A:3, dos. P 900 , SUK, RA.

${ }^{49}$ Memorandum regarding Virendranath Chattopadhyaya, (n.d.), vol. F10 A:3, dos. P 90 0, SUK, RA.

${ }^{50}$ Virendranath Chattopadhyaya, "Ett fult avgångsbetyg åt statsminister Sydow," Folkets Dagblad Politiken, 13 October 1921.

${ }^{51}$ Virendranath Chattopadhyaya, "En dolk, en revolver, en flaska kloroform som politiskt kampmedel," Folkets Dagblad Politiken, 14 October, 1921.

${ }^{52}$ Barooah, Chatto, 320-24.

53 “Har Dayal, Rebel, Recants His Views,” New York Times, 8 June 1919.

${ }^{54}$ Lala Har Dayal, "Poesin och Livet," Studiecirkeln, February 1920, 11.

${ }^{55}$ See: Dharmavira. Lala Har Dayal and Revolutionary Movements of His Time (New Delhi: Indian Book Company, 1970), 239-50.

${ }^{56}$ Teres Kaudern to Sven Strömberg, 7 April 1958, deposition 191, Svensk-indiska föreningen, $\mathrm{KB}$.

${ }^{57}$ Shruti Kapila, "Self, Spencer and Swaraj: Nationalist thought and critiques of liberalism, 1890-1920," Modern Intellectual History 4 (2007): 109-27.

${ }^{58}$ Lala Har Dayal. Hints for Self-Culture (London: Watts and Co, 1934). See also:

Daniel. J. Elam, "The Anti-colonial Ethics of Lala Har Dayal's Hints for Self

Culture," NMML Occasional Paper, History and Society New Series 9 (2013): 1-21.

${ }^{59}$ Lala Har Dayal, "Självbildningens metoder och mål," Studiecirkeln, September 1920, 41-42.

60 “Har Dayal of India, Author, Lecturer, 54,” New York Times, 7 March 1939. 